\title{
Screening Creditworthiness of SME's: The Case of Small Business Assistance in Turkey *
}

\author{
Selçuk Caner \\ International Monetary Fund, Washington D.C., USA \\ Mehment Baha Karan \\ Hacettepe University, Ankara, Turkey
}

In this paper we estimate creditworthiness of small and medium-sized enterprises (SMEs) that receive financial and non-financial incentives from the small business development administration (KOSGEB) in Turkey. Assessing creditworthiness of SMEs to qualify for government support remains a concern since standard methods based on financial information on firms would be inadequate due to lack of transparent financial information. Such businesses apply for government support because they would not qualify for funding from financial institutions. To assess the creditworthiness of these businesses other firm-level data is essential. A logit model is used to estimate riskiness of SMEs including non-financial data obtained from the business survey obtained by KOSGEB. We find that efficient and internationally competitive SMEs are unlikely to default. Firms with high creditworthiness are also managed by owners and focus on their core businesses. The model used in this paper provides a tool that can be used to better screen applicants seeking incentives as well as monitoring firms under a government support program. (JEL: G21, G33)

Keywords: Risk, creditworthiness, credit risk, default, SME, logit

\section{Introduction}

Measurement of credit riskiness of small and medium-sized enterprises

\footnotetext{
* This research was funded by TUBITAK under the grant SOBAG-106K003. We would like to thank the editor and the anonymous referee for their valuable comments and suggestions. Corresponding author: Mehment Baha Karan.
}

(Multinational Finance Journal, 2012, vol. 16, no. 1/2, pp. 1-20)

(C) Multinational Finance Society, a nonprofit corporation. All rights reserved.

DOI: $10.17578 / 16-1 / 2-1$ 
(SMEs) has become a major concern worldwide with the introduction of Basel II and the newly introduced Basel III principles. ${ }^{1}$ However, quality and the availability of SME data are problems that are yet to be completely addressed by credit institutions as well as regulators in both developed and developing economies. The probability of distress of firms due to fluctuations in their market value can be estimated if a sufficiently long history of asset price fluctuations exists. However, it is more complicated for firms with short financial history and no traded debt. In addition to relying on data from the financial statements, consideration should be given to the financial condition and history of the owners of the businesses as in many cases the firm and the owners are closely related in the case of SMEs (Mester, 1997). This is the problem faced by KOSGEB, the organization that supports the development of small and medium-sized enterprises (SMEs) in Turkey.

Credit risk assessment has practical as well as theoretical implications for the determination of cost of capital. As external financing requirements of the firms increase, the need for assessment of riskiness of borrowers also increases. Practitioners rely both on traditional as well as more recent proprietary models in determining the credit worthiness of firms. Interest in the determination of creditworthiness has increased since the study by Altman (1968) on estimating default risk using a multivariate discriminant analysis. Early studies based on traditional models can be classified as the expert systems which rely on the judgment of the assessor, rating systems, and credit scoring models. More recent models of risk assessment are structural and more advancedreduced-form models. ${ }^{2}$

However, application of the risk evaluation models on SMEs remains a problem. As a result, there are very few studies on the prediction of default of SMEs. Keasey and Watson (1986), Laitinen (1991) and Kiviluoto (1998) estimate credit risk of SMEs using discriminant analysis. Altman and Sabato (2007) use a logit model and conclude that banks should estimate different models for large firms and SMEs. They find accurate estimation of credit riskiness of SMEs would help expand the size of the credit markets. Rikkers and Ooghe (2009)

1. SMEs are classified as businesses with annual turnover of less than 50 million euros according to the Basel II Accord. The new liquidity and leverage requirements of Basel III may make it more difficult for SMEs to access bank finance.

2. See Merton (1974) on structural models, and Jarrow and Turnbull (1997) and Jones and Hensher (2009) on reduced-form models. 
suggest that combining structural models with the traditonal models can be useful in overcoming the inaccurate data problems associated with risk assessment of SMEs in the case of Dutch firms. Studies on credit risk in developing countries are even more limited due to the availability of reliable financial data. For example, there is only one study on Turkish businesses by Unal (1988) which concerns the creditworthiness of food processing firms. Kou et al. (2003) assess riskiness of SMEs in Taiwan.

KOSGEB is a non-profit, semi-autonomous public organization responsible for the growth and development of SMEs in Turkey. Its Board of Directors consists of representatives from the government and various business organizations. The primary objective of KOSGEB is to improve SMEs share and efficiency in the Turkish economy and to enhance their competitiveness. In order to accomplish this objective, KOSGEB has assumed the responsibility for the development of SMEs' technological skills, improving their training and information levels, providing appropriate financial mechanisms and enhancing their managerial infrastructure.

Given its limited funding sources, KOSGEB needs to assess not only the creditworthiness of businesses it supports, but that of new applicants to its programs as well. Identification of firms that are likely to fail would be useful in allocating resources more efficiently and stop supporting businesses that are more likely to be unsuccessful. KOSGEB's credit risk measurement problem can be resolved within a traditional credit scoring methodology often used by banks for SME loan approval. ${ }^{3}$

KOSGEB provides financial or in-kind support to about 12,500 small businesses nationwide. Considering the high real interest rates in Turkey, subsidized credits are highly valuable to small businesses. So the problem faced by KOSGEB is developing an appropriate and effective mechanism to fund for such credit services.

In this paper, we estimate the creditworthiness of a firm using a logit model that includes firm specific financial and managerial factors that determine the approval of an application for subsidized credit to an SME. The paper contributes to the existing literature by demonstrating the significance of non-financial factors as determinants of credt risk in the case of SMEs. We emphasize that non-financial factors are

3. According to Treacy and Carey (2000), about $70 \%$ of banks use a scoring method for SMEs before approval of a loan. 
significant in determining credit risk of SMEs as opposed to financial indicators emphasized in the literature. In an environment where financial data is either not reliable or does not have a suffcient history, firm charactersitcs are good predictors in revealing the financial healtiness of a firm. So, credit institutions can improve assessment of SME credtiworthiness by including non-financial data in addtion to financial data in their credti assessment models.

Institutions that provide financial support for the development and growth of SMEs are faced with a different group of businesses where standard financial information used in assessing creditworthiness is either inconsistent or unavailable. These businesses appeal to government-sponsored institutions because financial institutions either decline to fund them or provide very limited funding under very stringent terms. So, it is a challenge to find other reliable firm-level data that can provide information in the determination of default risk of such firms. We find that efficient SMEs with better capacity utilization and exposure to international competition are unlikely to default. The management structure of better run firms is either sole proprietorship or partnership. Furthermore, businesses that focus on their core activity are less likely to default. Another key determinant of riskness is the regional location of the business. In that sense, access to ports and transport are important. Businesses operating within close proximity to ports are less like to default.

In Section II we provide a description of the data and review similar studies. We present the model and discuss the data issues in Section III. In Section IV, we report the results of the estimations and interpret our findings. Robustness of the estimations is also provided. Section V concludes with suggestions on the use of credit default estimation of SMEs.

\section{The Data}

This is the first study done on the unique database on SMEs compiled by KOSGEB to estimate their riskiness. Determining the creditworthiness of SMEs that participate in the KOSGEB program is difficult because of problems in identifying those high risk firms at the application stage which are most likely to fail. Because of the subsidies, SMEs can continue to operate, while without the subsidies they would either go bankrupt or default in fulfilling their financial obligations. 
Traditionally, a failure can be defined as a declaration of bankruptcy, a default on payment or a liquidation.

The dataset is a cross-section of selected firms that receive any form of incentives from KOSGEB. The data is based on a survey of SMEs by KOSGEB on the activities of the companies in 2005, and has been conducted for 12,500 companies by KOSGEB. The firms included in the final dataset are firms that are admitted to the SME assistance program after a prior screening by KOSGEB. So, the sample firms do not necessarily represent the population of SMEs operating in Turkey. The survey consists of the following eight parts;

Company and Product Information

The Goals of the Firm

Market Structure of the Firm

Marketing Plan

Production Development Plan

Organization and Management Plan

Financial Plan

KOSGEB Supports

The survey contains many subjective questions aimed at obtaining information on the views of the owners about their businesses. So, we relied mostly on the financial, managerial and production information included in the survey. The financial plan of the survey contains information about the financial statements and activities of the company that are declared by the owners or finance staff of the companies. Although this information is partly subjective by nature, it is expected to reflect more accurate information than the financial statements presented to tax authorities. This information is kept confidential and not shared with third parties, a principle of KOSGEB. Also, experienced examiners of KOSGEB are skillful in obtaining accurate information and verifying the quality of disclosures by the firms.

The data obtained from KOSGEB have no company identifiers and each company is assigned a numeric code. In addition, street names and detailed addresses of the companies are not obtained due to the privacy of the data. The financial information of the firms and the information concerning the location, age of the companies, number of shareholders and employees are used as variables in the study. The raw data of the survey is reorganized and the companies that have not filled out key 
financial data or where individuals items did not add up to total reported elsewhere in the reports are deleted from the files. Furthermore, the data are cleaned up so that only firms with complete information are included in the data set. Then, the data are merged with another data set that included only credit applications. The two data files are merged by name and a unique identification number. The dataset with the credit application information is provided by a number of banks that cooperate with KOSGEB in the evaluation and distribution of credits. Finally, after excluding outliers such as extremely high (or low) financial ratios that may be due to inaccurate reporting, the reduced number of firms included in the analysis is 2,473 . While the survey includes companies from all regions of Turkey, a large majority of those companies are located in highly developed Western regions like Marmara and the Aegean, and in fact, forty percent of the companies are located in the Marmara region alone.

The SMEs applying for a KOSGEB credit can be classified into three groups. Some firms receiving subsidies from KOSGEB are new firms or firms with a short history so, they do not have a sufficiently long credit history for banks to consider them as good risk. The second group consists of firms that would like to take advantage of the subsidized terms of a KOSGEB loan. The third group of SMEs includes firms that have no chance of survival but apply as a last recourse because, they have no other way to continue operations. These firms apply because they anticipate some political influence in the decision process of lending by KOSGEB. The rejected applicants mostly come from this group of firms. It is possible for some firms in this group to receive loans as a result of political favors. Ex-post review by KOSGEB identified that 206 SMEs either stopped operations or are in the process of liquidation two years after applications for a loan. It is this group that consists of the sample of defaulted firms used in the estimations. Out of 206 firms, 158 failed after been denied a credit. In addition, 48 firms out of the credit recipients failed.

For estimation purposes the key sets of data are obtained from the balance sheet, the income statement and firm characteristics. Earnings and cash flow; asset value, liquidity and leverage; and debt capacity are considered basic information needed to determine riskiness of a firm. Since ratios are more stable over time, data from financial statements is used in the form of ratios in predicting rejection of a loan application. Two reviews of the literature (Peel and Wilson (1987), Taffler and Tseung, 1984) identify three significant indicators of financial distress: 
low working capital; negative net profits; and auditor reports indicating business is no longer viable in the near future.

Data from the balance sheet consists of total assets (TA) as the sum of total liability and net worth. Working capital (WC) is defined as the difference between current assets (CA) less current liabilities (CL). In addition, fixed worth (FW) is used as the difference between fixed assets (FA) and long-term debt (LTD). Net worth (NW) of a business can be obtained as the sum of WC and FW from the balance sheet. Data from income statements are sales, earnings before interest and taxes (EBIT) as operating profit, earnings before interest, taxes, depreciation and amortization (EBITDA) and net profits. Major financial ratios used in the estimations provide information on earnings, interest coverage, capital structure and asset quality.

Altman (1968) uses WC/TA, Retained Earnings/Total Assets (RE/TA), EBIT/TA, Book Equity/TA, Sales/TA in his estimations as predictors of a default event. His model has persisted as the standard model for decades and still continues to do so. Generally, financial ratios are used as predictor variables in models that forecast business distress and failure (Altman 1968). Standard ratios used by Altman (2007), such as operating income coverage, free cash flow, total debt coverage and long-term debt coverage are included in the model. However, as argued by Ooghe and Balcean (2007) on Belgian firms and, Gruszczynski (2004) for Polish firms, the model results are sensitive to the choice of explanatory variables. Furthermore, as indicated in Altman (2007) for SMEs, non-financial qualitative variables are also important determinants of risk. The model includes such factors as ownership, form of business organization and, the number and type of of employees. Also included in estimations are management performance in terms of managing operations and the ownership structure of the business. $^{4}$

In addition to financial ratios, Mensah (1984) and, Lopez-Garcia and Puente (2006) include macroeconomic factors as predictors over the business cycle. Mannasoo and Mayes (2009), Tirapat and Nittayagasetwat (1999) find strong influence of macroeconomic and structural factors. However, we do not include any macroeconomic variables in the estimates because the data is cross-sectional.

The dependent variable is a dummy variable that takes on a value of

4. Doumpos and Zopounidis (1999) find that managerial inability to organize and compete has a significant impact on the probability of distress. 
one or zero. The dummy variable for a firm that failed in the following year or two is assigned a value of one while a surviving firm is given a value of zero. ${ }^{5}$

\section{Summary Statistics}

Summary statistics on the characteristics of the firms are presented in table 1. Firms can apply for four different types of credit. To qualify for a credit a firm has to operate in the leather, transportation equipment, processed food, or machinery industries. They can also apply for export and employment credits. Most firms apply for an export or an employment credit. The firms are separated according to the dummy variable which identifies whether a firm is failed or successfully continuing its operations. About 206 firms have failed in 2007 while 2,267 firms survived. Failed firms are characterized by low profit margins, low capacity utilization and low international sales.

The firm-specific variables include the location, the age of the firm, the legal form of the business, the number of shareholders and the ratio of white to blue collar workers. There are no discriminating differences among the firms in terms of business organization and the diffusion of ownership.Firms with better credit standings are engaged in exports. Furthermore, $12.5 \%$ of the firms have been operating less than 5 years. One can conclude that the firms included in the sample have a good survival rate. This is due to the sufficient creditworthiness of older firms with accumulated collateral. More than $57 \%$ of the good credit firms have been in business longer than 10 years while more than $46 \%$ of the poor credit firms have been operating less than 10 years.

Most of the firms in the sample are organized as limited liability corporations (LLC) due to the concentration of ownership amongst a few shareholders. Most firms in Turkey are organized as LLCs, as this ownership structure is efficient for reporting purposes. It further limits liability while providing control of the business to the owners. The shares of limited liability companies (LLC) and corporations are

5. Choice of a default indicator may be different than bankruptcy. A review of the relevant literature (Peel and Wilson (1987)) suggests three prime indicators of acute financial distress: low working capital; negative net profit before tax; and accounts qualified on the going-concern basis, i.e., where such a qualification is given in the auditors' report' only on the basis that it might not continue in operational existence for the foreseeable future' (Taffler and Tseung, 1984). 
TABLE 1. Characteristics of Good and Poor Credit Firms

\begin{tabular}{|c|c|c|c|}
\hline & Successful & Failed & Total \\
\hline \multicolumn{4}{|l|}{ Type of Credit } \\
\hline Leather- Transportation Industry (1) * & $\begin{array}{l}3 \\
0.13 \%\end{array}$ & $\begin{array}{l}2 \\
0.97 \%\end{array}$ & $\begin{array}{l}5 \\
0.20 \%\end{array}$ \\
\hline Processed Food - Machinery Industry (2) & $\begin{array}{l}31 \\
1.37 \%\end{array}$ & $\begin{array}{l}13 \\
6.31 \%\end{array}$ & $\begin{array}{l}44 \\
1.78 \%\end{array}$ \\
\hline Exports (3) & $\begin{array}{l}1,342 \\
59.20 \%\end{array}$ & $\begin{array}{l}53 \\
25.73 \%\end{array}$ & $\begin{array}{l}1,395 \\
56.41 \%\end{array}$ \\
\hline Employment (4) & $\begin{array}{l}891 \\
39.30 \%\end{array}$ & $\begin{array}{l}90 \\
43.69 \%\end{array}$ & $\begin{array}{l}981 \\
39.67 \%\end{array}$ \\
\hline Bankruptcy (5) & $\begin{array}{l}0 \\
0.00 \%\end{array}$ & $\begin{array}{l}48 \\
23.30 \%\end{array}$ & $\begin{array}{l}48 \\
1.94 \%\end{array}$ \\
\hline Total & $\begin{array}{r}2,267 \\
100.00 \%\end{array}$ & $\begin{array}{l}206 \\
100.00 \% \\
\end{array}$ & $\begin{array}{l}2,473 \\
100.00 \% \\
\end{array}$ \\
\hline \multicolumn{4}{|l|}{ Number of Years in Existence } \\
\hline $0-2$ & $\begin{array}{l}82 \\
3.62 \%\end{array}$ & $\begin{array}{l}49 \\
23.79 \%\end{array}$ & $\begin{array}{l}131 \\
5.30 \%\end{array}$ \\
\hline $3-5$ & $\begin{array}{l}293 \\
12.93 \%\end{array}$ & $\begin{array}{l}16 \\
7.77 \%\end{array}$ & $\begin{array}{l}309 \\
12.50 \%\end{array}$ \\
\hline $6-9$ & $\begin{array}{l}590 \\
26.03 \%\end{array}$ & $\begin{array}{l}45 \\
21.85 \%\end{array}$ & $\begin{array}{l}635 \\
25.68 \%\end{array}$ \\
\hline 10 and more & $\begin{array}{r}1,302 \\
57.39 \%\end{array}$ & $\begin{array}{l}96 \\
46.12 \%\end{array}$ & $\begin{array}{l}1,398 \\
56.45 \%\end{array}$ \\
\hline Total & $\begin{array}{l}2,267 \\
100.00 \%\end{array}$ & $\begin{array}{l}206 \\
100.00 \% \\
\end{array}$ & $\begin{array}{l}2,473 \\
100.00 \% \\
\end{array}$ \\
\hline \multicolumn{4}{|l|}{ Business Form } \\
\hline Sole Proprietorship & $\begin{array}{l}137 \\
6.04 \%\end{array}$ & $\begin{array}{l}17 \\
8.25 \%\end{array}$ & $\begin{array}{l}154 \\
6.23 \%\end{array}$ \\
\hline Limited Liability Corporation & $\begin{array}{r}1,473 \\
64.98 \%\end{array}$ & $\begin{array}{l}124 \\
60.19 \%\end{array}$ & $\begin{array}{l}1,597 \\
64.58 \%\end{array}$ \\
\hline Corporation & $\begin{array}{l}639 \\
28.19 \%\end{array}$ & $\begin{array}{l}64 \\
31.07 \%\end{array}$ & $\begin{array}{l}703 \\
28.43 \%\end{array}$ \\
\hline General Partnership & $\begin{array}{l}11 \\
0.49 \%\end{array}$ & $\begin{array}{l}0 \\
0.00 \%\end{array}$ & $\begin{array}{l}11 \\
0.45 \%\end{array}$ \\
\hline Limited Partnership & $\begin{array}{l}4 \\
0.18 \%\end{array}$ & $\begin{array}{l}0 \\
0.00 \%\end{array}$ & $\begin{array}{l}4 \\
0.16 \%\end{array}$ \\
\hline Other & $\begin{array}{l}3 \\
0.13 \%\end{array}$ & $\begin{array}{l}1 \\
0.49 \%\end{array}$ & $\begin{array}{l}4 \\
0.16 \%\end{array}$ \\
\hline Total & $\begin{array}{l}2,267 \\
100.00 \%\end{array}$ & $\begin{array}{l}206 \\
100.00 \%\end{array}$ & $\begin{array}{l}2,473 \\
100.00 \%\end{array}$ \\
\hline
\end{tabular}

( Continued) 
TABLE 1. (Continued)

\begin{tabular}{lccc}
\hline & Successful & Failed & Total \\
\hline Number of Shareholders & & & \\
\hline $1-2$ & 992 & 86 & 1,078 \\
& $43.78 \%$ & $41.95 \%$ & $43.63 \%$ \\
$3-5$ & 980 & 84 & 1,064 \\
& $43.25 \%$ & $40.98 \%$ & $43.06 \%$ \\
$6-9$ & 248 & 26 & 274 \\
& $10.94 \%$ & $12.68 \%$ & $11.09 \%$ \\
10 and more & 46 & 9 & 55 \\
& $2.03 \%$ & $4.39 \%$ & $2.23 \%$ \\
Total & 2,266 & 205 & 2,471 \\
& $100.00 \%$ & $100.00 \%$ & $100.00 \%$ \\
\hline
\end{tabular}

Note: The table tabulates the distribution of the SMEs by firm characteristics. In addition, firm characteristics are separately tabulated for successful and failed firms. Firm characteristics are grouped according to the types of credit, length of survival, business form and size of ownership. $*$ The first row is the number of firms, the second row is the share in total.

respectively $65 \%$ and $28 \%$. Companies generally have few partners; this is the general tendency of the small businesses in Turkey. Indeed, $87 \%$ of the firms have less than 6 shareholders. About $44 \%$ of the firms are owned by one or two shareholders.

Considering the data on the number of white and blue-collared employees, we can conclude that the sample companies are generally very small. The mean number of blue-collared employees is 28 while the average number of white collared employees is 7.

KOSGEB's financial assistance is available to qualifying firms countrywide. In the dataset, $24.1 \%$ of the firms are located in Istanbul, 7.9\% in Izmir, 6.8\% in Ankara and 6.6\% in Bursa. While most of the firms are located in major metropolitan areas, KOSGEB provides assistance to firms in 73 cities out of a total of 81 cities nationwide.

In table 2 we include some of the commonly used variables used in the credit risk studies. Financial ratios are common factors used in the estimations. In addition, some of the studies include institutional characteristics as well (See, Kou, (2003)). We test all the commonly used financial ratios as explanatory variables in the estimations; however, not all were significant. Also, we find some firm characteristics that were significant in other studies not to be significant in the case where financial data is infrequent and not complete. 
TABLE 2. Selected Commonly-Used Explanatory Variables

\begin{tabular}{|c|c|}
\hline Explanatory Variables & Explanation \\
\hline Current Ratio & Altman (1968) \\
\hline Sales/Assets & Altman (1968), Theodossiou (1992) \\
\hline Net Income/Assets & $\begin{array}{l}\text { Altman (1968), Theodossiou(1992), } \\
\text { Kou, et.al. (2003) Jones and Hensher (2004) }\end{array}$ \\
\hline Total Debt/Total Assets & $\begin{array}{l}\text { Altman (1968), Theodossiou(1992, 1996), } \\
\text { Kou, et.al. (2003), Jones and Hensher (2004) }\end{array}$ \\
\hline Fixed Assets/Total Assets & Altman (1968) \\
\hline Capacity Usage & Kou, et.al. (2003) \\
\hline Share of International Sales & Kou, et.al. (2003) \\
\hline
\end{tabular}

Note: Commonly used variables indicate the importance of mostly financial variables.

Table 3 includes summary statistics of the variables used in the final model. In the table, separate descriptive statistics are provided for surviving and failed firms. The table highlights the differences between the two types of firms. Separating the data by types of firm, one can observe that good firms are able to maintain higher levels of liquidity than the poor firms, but the mean difference of good and poor credits is not significant. Good firms also have a larger share of exports in total sales which is significant. In addition, one other significant factor is the capacity usage. While good firms operate at $72.5 \%$ capacity, failed firms are much less efficient, operating at $49 \%$ capacity usage.

As seen in table 3, the differences in the means of commonly used financial ratios used by Altman (1968) and others were not significant excluding the Sales/Assets ratio. CurrentRatio, NetIncome/Assets, TotalDebt/Assets, FixedAssets/Assets were not significant. These variables are also not significant in the estimations when included in the model. One can attribute the insignificance of the financial ratios to the quality of financial statements provided by the SMEs. Another possible explanation is that some of the assets of the firms are personal property of the owners. All explanatory variables used in the estimations have low correlation implying that the estimates would not be biased by multicollinearity. ${ }^{6}$

6. Correlation coefficients between the ratios used in the model range between -0.029 and 0.069 . 
TABLE 3. Summary Statistics for the Explanatory Variables

\begin{tabular}{|c|c|c|c|c|}
\hline Variable & & $\begin{array}{c}\text { Successful } \\
0\end{array}$ & $\begin{array}{c}\text { Failed } \\
-1\end{array}$ & $\begin{array}{c}\text { Differences } \\
t \text {-value }\end{array}$ \\
\hline \multirow[t]{5}{*}{ Current Ratio } & Mean & 1.722 & 1.685 & 0.297 \\
\hline & Std. Dev. & 1.706 & 1.731 & 0.467 \\
\hline & Median & 1.191 & 1.110 & \\
\hline & Min. & 0.206 & 0.225 & \\
\hline & Max. & 14.600 & 12.823 & \\
\hline \multirow[t]{5}{*}{ Share of International Sales } & Mean & 28.463 & 20.311 & $3.649 * * *$ \\
\hline & Std. Dev. & 30.746 & 30.154 & $3.700 * * *$ \\
\hline & Median & 16.000 & 3.500 & \\
\hline & Min. & 0.000 & 0.000 & \\
\hline & Max. & 100.000 & 100.000 & \\
\hline \multirow[t]{5}{*}{ Capacity Utilization } & Mean & 72.463 & 49.461 & $13.437 * * *$ \\
\hline & Std. Dev. & 21.961 & 36.584 & $219.950 * * *$ \\
\hline & Median & 75.000 & 60.000 & \\
\hline & Min. & 1.000 & 0.000 & \\
\hline & Max. & 100.000 & 100.000 & \\
\hline \multirow[t]{5}{*}{ White Col./Blue Col } & Mean & 0.777 & 0.591 & 0.883 \\
\hline & Std. Dev. & 4.467 & 1.902 & 1.342 \\
\hline & Median & 0.242 & 0.250 & \\
\hline & Min. & 0.000 & 0.000 & \\
\hline & Max. & 126.000 & 20.000 & \\
\hline \multirow[t]{5}{*}{ Mark. Sec./Total Assets } & Mean & 0.101 & 0.107 & -0.704 \\
\hline & Std. Dev. & 0.108 & 0.114 & 0.609 \\
\hline & Median & 0.067 & 0.077 & \\
\hline & Min. & 0.000 & 0.000 & \\
\hline & Max. & 0.825 & 0.733 & \\
\hline \multirow[t]{5}{*}{ Sales/Assets } & Mean & 21.891 & 10.381 & $1.668 *$ \\
\hline & Std. Dev. & 98.375 & 37.126 & $9.560 * * *$ \\
\hline & Median & 10.503 & 9.485 & \\
\hline & Min. & 0.000 & 0.097 & \\
\hline & Max. & 1451.370 & 313.273 & \\
\hline \multirow[t]{5}{*}{ Net Income/Assets } & Mean & 15.581 & 8.696 & 1.141 \\
\hline & Std. Dev. & 85.832 & 37.132 & $4.803 * * *$ \\
\hline & Median & 0.086 & 0.066 & \\
\hline & Min & -424.512 & -0.261 & \\
\hline & Max. & 1450.283 & 313.273 & \\
\hline \multirow[t]{5}{*}{ Total Debt/Total Assets } & Mean & 0.591 & 0.594 & -0.205 \\
\hline & Std. Dev. & 0.215 & 0.233 & $2.852 * *$ \\
\hline & Median & 0.600 & 0.600 & \\
\hline & Min & 0.002 & 0.029 & \\
\hline & Max. & 0.998 & 0.968 & \\
\hline
\end{tabular}

( Continued) 
TABLE 3. (Continued)

\begin{tabular}{|c|c|c|c|c|}
\hline Variable & & $\begin{array}{c}\text { Successful } \\
0\end{array}$ & $\begin{array}{c}\text { Failed } \\
-1\end{array}$ & $\begin{array}{c}\text { Differences } \\
t \text {-value }\end{array}$ \\
\hline \multirow[t]{5}{*}{ Fixed Assets/Total Assets } & Mean & 0.305 & 0.316 & -0.679 \\
\hline & Std. Dev. & 0.224 & 0.252 & $10.652 * * *$ \\
\hline & Median & 0.283 & 0.283 & \\
\hline & Min. & 0.000 & 0.000 & \\
\hline & Max. & 0.974 & 0.971 & \\
\hline \multirow[t]{5}{*}{ Corporation } & Mean & 0.282 & 0.311 & -0.877 \\
\hline & Std. Dev. & 0.450 & 0.464 & $2.746 * *$ \\
\hline & Median & 0.000 & 0.000 & \\
\hline & Min. & 0.000 & 0.000 & \\
\hline & Max. & 1.000 & 1.000 & \\
\hline \multirow[t]{5}{*}{ Black Sea } & Mean & 0.059 & 0.102 & $-2.462 * *$ \\
\hline & Std. Dev. & 0.235 & 0.303 & $22.492 * * *$ \\
\hline & Median & 0.000 & 0.000 & \\
\hline & Min. & 0.000 & 0.000 & \\
\hline & Max. & 1.000 & 1.000 & \\
\hline \multirow[t]{5}{*}{ Aegean } & Mean & 0.206 & 0.277 & $-2.379 * *$ \\
\hline & Std. Dev. & 0.405 & 0.448 & $18.300 * * *$ \\
\hline & Median & 0.000 & 0.000 & \\
\hline & Min. & 0.000 & 0.000 & \\
\hline & Max. & 1.000 & 1.000 & \\
\hline
\end{tabular}

Note: The table tabulates key statistics on variables used in the estimations. The number of successful and failed firms are 2,267 and 206 respectively. ***, ** and * denote statistical significance at the $1 \%, 5 \%$ and $10 \%$ levels.

\section{The Model}

Creditworthiness can be determined by the most commonly used models such as the linear probability model, the logit model, the probit model, discriminant analysis and neural networks. Aziz et al. (1988), Platt and Platt (1990) Ooghe et al. (1995) and Becchetti and Sierra (2002) all use logit models for predicting defaults. For many years multivariate discriminant models remained the main statistical method used in predicting defaults. While discriminant models were successful in predicting defaults, the coefficients of the variables were difficult to interpret. Since the mid-1980s, there has been an increase in the use of logit models in estimating default prediction.

Statistically, logit models fit better in explaining the sources of defaults. Lo (1985) compares the predictive power of logit and discriminant models and concludes that logit models perform better. 
Papoulias and Theodossiou (1992) test a number of models to predict failure rates of manufacturing firms in Greece. They find that all models have good prediction power in predicting failures. Furthermore, Theodossiou et. al. (1996) were able to explain the acquisition decisions of distressed firms using a sequential logit model. Allen (2007) provides an excellent survey of different approaches used in estimating riskiness of firms. Gaermynck and Willekens (2003) and, Jones and Hensher $(2004,2009)$ obtain a prediction rate of $70 \%-95 \%$ in predicting defaults using logit models.

A logit model is used for estimating the probability of creditworthiness of SMEs included in the KOSGEB's database. A common representation of the logit model in estimating the probability for qualifying for credit is as follows: ${ }^{7}$

$$
P_{t}\left(Y_{i}\right)=Y_{i} F\left(\beta X_{i, t-1}\right)+\left(1-Y_{i}\right)\left[1-F\left(\beta X_{i, t-1}\right)\right]
$$

where $X_{i, t-1}=\left[1, X_{1, t-1}, \ldots, X_{k, t-1}\right]$ is a vector that includes the explanatory variables of the model ( 1 is for the model's intercept) and $\beta$ is a vector of logit coefficients corresponding to the explanatory variables. $P_{t}$ takes the value of 1 if firm $i$ fails in year $t$ and 0 otherwise.

According to the above model, the probability that a firm with an attribute vector $X$ being a poor credit firm is

$$
P_{t}\left(Y_{i}=1\right)=F\left(\beta X_{i, t-1}\right)
$$

and the probability of being a good credit firm

$$
P_{t}\left(Y_{i}=0\right)=1-F\left(\beta X_{i, t-1}\right)
$$

where

$$
F\left(\beta X_{i, t-1}\right)=\int_{-\infty}^{\beta X_{i, t-1}} d F(z)=1 /\left[1+\exp \left(\beta X_{i, t-1}\right)\right]
$$

is the cumulative probability for the logistic probability function.

The probabilities are determined by a vector of firm specific variables $X_{i}$. The variable $X_{i, t-1}$ is related to the dependent dummy variable positively or negatively depending on the contribution of $X_{i, t-1}$

7. See, Park and Perestani (1998). 
on $P_{t}$. The coefficients of the model are estimated by the maximum likelihood method.

\section{Estimation Results}

The estimation results are presented in table 4. The explanatory variables included in the model are financial ratios and selected firm characteristics. We include regional dummies to account for regional differences. Only two regional dummies are significant. Each independent variable is selected according to the univariate test of significance. The variable with the highest $t$-value is introduced into the estimation model first. The rest of the variables are introduced individually according to the size of the $t$-value of each variable. Insignificant variables are removed from the estimation model one at a time and replaced by significant variables. A negative coefficient implies that an increase in the independent variable would reduce the probability of default.

None of the financial ratios introduced in the model are significant except the marketable securities to asset ratio. This finding questions the reliability of the financial data provided by the firms. While this is unusual, it should not be a surprise because, the very reason these firms are seeking funds from a government sponsored entity is that they would not qualify as a good risk by private banks that base their lending decisions on the financial soundness of the firm alone.

The ratio of marketable securities to assets has the expected positive sign. A firm with a higher share of its assets allocated in assets not directly related to its core business cannot be expected to stay in operation for long. Particularly, the 2003-2006 period which includes the sample period was a period of high growth in Turkey. One would expect the firms to invest in their core businesses rather than financial assets. Capacity utilization has a negative coefficient implying that as the firm uses more of its resources the probability of a failure would decrease. This is expected since high capacity utilization implies profitability. The sign of the coefficient of share of international sales is also negative. Firms with higher shares of their production exported are less likely to fail. This is because, these firms operate in a more competitive environment. This result is consistent with the high growth in exports in the 2003-2007 period. They are expected to be more efficient relative to other firms producing for the domestic market. 
TABLE 4. Parameter Estimates of the Logit Model

\begin{tabular}{|c|c|c|c|c|}
\hline Parameter & Estimate & $t$-statistic & $\begin{array}{c}\text { Wald } \\
\text { Chi-Square }\end{array}$ & $\exp (\beta)$ \\
\hline Constant & -0.572 & -2.918 & 8.514 & 0.565 \\
\hline Marketable Securities/Assets & 1.081 & 1.648 & 2.719 & 2.949 \\
\hline Capacity Utilization & -0.032 & -10.667 & 137.903 & 0.969 \\
\hline Share of International Sales & -0.008 & -2.667 & 8.221 & 0.992 \\
\hline Incorporation & 0.204 & 1.222 & 1.498 & 1.226 \\
\hline Regional Dummy - Black Sea & 0.572 & 2.111 & 4.476 & 1.773 \\
\hline Regional Dummy - Aegean & 0.493 & 2.785 & 7.773 & 1.637 \\
\hline-2 Log Likelihood $=$ & $1,251.00$ & & & \\
\hline McFadden's R-square = & 0.118 & & & \\
\hline
\end{tabular}

Note: Table tabulates the estimated coefficients of the variables used in the estimation. We only report the coefficients of significant variables. The last column includes the estimated odd-ratio which is the measure of response of a failure to the variable. It is a measure of elasticity. Log likelihood ratio is used for testing the null hypothesis of all coefficients being insignificant.

The coefficient of the level of incorporation has a positive sign implying that incorporated firms are more likely to fail. This can be explained by the fact that these firms are not sufficiently large to be incorporated. More than $90 \%$ of the firms have fewer than 10 shareholders. A more suitable form of business is either a partnership or a limited liability corporation with few shareholders. Large management for decision making is not appropriate for the SMEs.

The coefficients of the two regional dummies, one for the Black Sea one for the Aegean region, have positive signs. ${ }^{8}$ Firms located in these regions have a higher chance of failure than firms located in the vicinity of Istanbul. Most of the SMEs in the sample are located in the Marmara region. ${ }^{9}$ This region has a variety of firms so, it was not possible to identify firms as good firms or bad firms just because they are located in the Marmara region. Location in a developed region is not a determining factor of default probability. The odds ratios (last column in table 4) imply a strong response of default to marketable securities ratio, regional location and the type of business organization. To test for the accuracy of the estimations, Type I and II errors are calculated and reported in table 5. Type I and II errors, measure the predictive

8. Dummy variables for other regions were not significant in the estimations.

9. Istanbul is located in the Marmara region. 
TABLE 5. Type I and Type II Error Rates

\begin{tabular}{|c|c|c|c|}
\hline & Successful Firms & Failed Firms & \\
\hline Cut-off Probability & $\mathrm{N}=2,061$ & $\mathrm{~N}=206$ & Expected Cost \\
\hline 0.05 & $53.35 \%$ & $21.40 \%$ & $37.38 \%$ \\
\hline 0.075 & $32.30 \%$ & $41.32 \%$ & $36.81 \%$ \\
\hline$\underline{0.1}$ & $21.00 \%$ & $\underline{48.10 \%}$ & $34.46 \%$ \\
\hline 0.2 & $6.00 \%$ & $65.00 \%$ & $35.50 \%$ \\
\hline 0.3 & $1.60 \%$ & $72.80 \%$ & $37.20 \%$ \\
\hline
\end{tabular}

Note: The error rates show the share of firms classified incorrectly by the logit model for each group of firms. The error rates are calculated for various cut-off probabilities. The expected cost function is calculated using eq. (5) with equal weights for error rates.

power of the model. Following Theodossiou (1996) we calculate the probability of Type I and Type II errors by minimizing the following cost function:

$$
\min _{f} E(C)=w_{g} p_{g}+w_{p} p_{p}
$$

where $p_{g}=\operatorname{Prob}\left\{F_{i}>f \mid\right.$ goodrisk $\}$ is the probability of classifying a good firm as a poor risk firm and $p_{p}=\operatorname{Prob}\left\{F_{i}<f \mid\right.$ poorrisk $\}$ is the probability of classifying a poor quality firm as a good risk firm. The weights $w_{g}$ and $w_{p}$ are assigned for each misclassification. In the calculations they are generally assumed to be 0.5 each. The parameter ' $f$ ' is a cut-off probability used to determine the percent of firms that are misclassified.

The estimated cost of error for various error rates for misclassifying ranges from $34.46 \%$ to $37.38 \%$. The cost of error is minimized at a cut-off rate of $10 \%$. At that level, the model misclassifies $21 \%$ of good firms while $48 \%$ of the poor risk firms are misclassified. While the model predicts good quality firms with great accuracy, it does not perform well in rejecting the poor quality firms. One possible explanation for this outcome is the lack of financial variables usually included in default estimation models.

\section{Conclusions}

Estimation of creditworthiness of SMEs is a major problem due to the limited sources and quality of data. Data on SMEs suffer from inconsistencies and underreporting. While the size of underreporting and unregistered economy remains high, KOSGEB has the difficult task 
of providing incentives to qualifying SMEs. It has to identify firms that are not likely to fail and allocate its funds. In addition to data quality problems, KOSGEB has to choose an appropriate methodology to determine the qualifying SMEs without any political interference.

A good credit assessment model must be based on accurate financial data on SMEs. While company tax returns can be considered as a good source for information on the financial condition of businesses, tax return data are highly unreliable for credit assessment purposes in Turkey. This study develops a unique data set on SMEs and estimates credit riskiness of SMEs. Out of more than 12,500 SMEs, the sample was reduced to about 2,473 after matching with credit records.

We first identify the factors that determined the probability of a failure for SMES. Using the model, we argue that KOSGEB can improve the assessment of riskiness of the firms that it provides assistance to, as well as to potential applicants. The novelty of the study is in the application of a risk assessment model in the context of assistance to a large body of SMEs. Further, we find that non-financial factors are significant determinants of default risk.

The only significant financial variable was the ratio of marketable securities to assets in the determination of default probability. Other financial ratios commonly used in the literature were not significant. However, investment in core business, capacity utilization, export orientation, form of business and the share of white-collared employees and location are among the factors that determine the failure probability of an SME. The results have several implications for allocating assistance to SMEs. First and foremost, improving the quality of financial data is important. Key predictors of distress are not significant implying financial statements do not properly reflect the financial conditions of the firm. The results also indicate the importance of non-financial factors such as efficient use of resources, represented by capacity utilization. Competitiveness with the rest of the world is also a significant factor for firm distress. Firms engaged in international trade reduce the likelihood of distress. KOSGEB would better use its fund by supporting companies that are more efficient and have the ability to compete internationally.

To improve the prediction power of this model, KOSGEB has to monitor and audit the firms more closely. Once the quality of the data is improved, especially the financial data, it would contribute significantly to the reduction of unregistered economy in Turkey and conformity with the recently introduced Basel III principles.

Accepted by: Prof. P. Theodossiou, Editor-in-Chief, October 2011 


\section{References}

Allen, L. 2007. Credit Risk Modeling of Middle Markets. Working Paper. Baruch College, CUNY.

Altman, E. I., and Sabato, G. 2007. Modeling Credit Risk for SMEs: Evidence from the US Market. Abacus 43: 332-357.

Altman, E.I. 1968. Financial Ratios, Discriminant Analysis, and the Prediction of Corporate Bankruptcy, Journal of Finance, 23: 589-609.

Aziz, A.; Emanuel, D.C.; and Lawson, G.H. 1988. Bankruptcy Prediction - An Investigation of Cash Flow Based Models. Journal of Management Studies 25: 419-437.

Becchetti, L., and Sierra, J. 2003. Bankruptcy Risk and Productive Efficiency in Manufacturing Firms. Journal of Banking and Finance, 27: 2099-2120.

Doumpos, M. and Zopounidis, C. 1999. A Multicriteria Discrimination Method for the Prediction of Financial Distress: The Case of Greece. Multinational Finance Journal, vol. 3, no. 2, pp. 71-101.

Gaeremynck, A., and Willekens, M. 2003. The Endogenous Relationship Between Audit Report Type and Business Termination: Evidence on Private Firms in a Non-litigious Environment. Accounting and Business Research 33(1): 65-79.

Gruszczynski, M., (2004) Financial Distress of Companies in Poland. International Advances in Economic Research, November, 10, No. 4: 249-256.

Jarrow, R. and Steve Turnbull, 1997. Derivative Securities, South-Western College Publishing.

Jones, S., and Hensher, D. 2009. Advances in Credit Risk Modelling and Corporate Bankruptcy Prediction', Cambridge University Press, Cambridge, United Kingdom, 2009.

Jones , S., and Hensher, D. 2004. Predicting Firm Financial Distress: A Mixed Logit Model. The Accounting Review 79 (1):1011-1038.

Keasey, K., and Watson, R. 1986. The Prediction of Small Company Failure: Some Behavioral Evidence for the U.K. Accounting and Business Research, 17: 49-57.

Kiviluoto, K. 1998. Predicting Bankruptcies with the Self-Organizing Map. Neurocomputing 21 (1-3): 191-201.

Kuo, H. C.; Wang, L.; and Sheu, H. 2003. Credit Evaluation for Small and Medium-sized Enterprises by the Examination of Firm-specific Financial Ratios and Non-financial Variables: Evidence from Taiwan. Review of Pacific Basin Financial Markets and Policies 6: 5-20.

Laitinen, E. 1991. Financial Ratios and Different Failure Processes. Journal of Business Finance and Accounting 18(5): 649-673.

Lo, A. W.1985. Logit Versus Discriminant Analysis. Journal of Econometrics 31: 151-178.

López-García P. and Puente S., 2006, "Business demography in Spain: 
determinants of firms survival", Banco de España, Working Paper No. 0608.

Mannasoo, K. and Mayes, D. 2009. Explaining bank distress in Eastern European transition economies. Journal of Banking and Finance 33: 244-253.

Mensah, Y. M. 1984. An Examination of the Stationarity Multivariate Bankruptcy Prediction Models: A Methodology Study. Journal of Accounting Research 22: 380-395.

Merton, R. 1974. On the Pricing of Corporate Debt: The Risk Structure of Interest Rates, Journal of Finance, 28, 449-470.

Mester, L. 1997. What is the Point of Credit Scoring? Federal Reserve Bank of Philadelphia Business Review September/October: 3-16.

Moody's Investor Service. 2002. Corporate Default and Recovery Rates: 1920-2006. Moody's Publication.

Ooghe, H.; Joos, P.; and Bourdeaudhuij, C. D. 1995. Financial Distress Models in Belgium: The Results of a Decade of Empirical Research. The International Journal of Accounting 30: 245-274.

Ooghe, H., and Balcaen, S. 2007. Are Failure Prediction Models Widely Usable? An Empirical Study Using a Belgian Dataset. Multinational Finance Journal, vol. 11, no. 1/2, pp. 33-76).

Papoulias, C., and Theodossiou, P. 1992. Analysis and Modeling of Recent Business Failures in Greece. Managerial and Decision Economics 13: 163-169.

Peel, M. J., and Wilson, N. 1989. The Liquidation/Merger Alternative Some Results for the UK Corporate Sector. Managerial and Decision Economics 10: 209-220.

Platt, H.D., and Platt, M.B., 1990. Development of a Class of Stable Predictive Variables: The Case of Bankruptcy Prediction. Journal of Business Finance and Accounting 17:31-51.

Rikkers, F. and Ooghe, H. 2009. A Structural form Default Prediction Model for SMEs, Evidence from the Dutch Market. Multinational Finance Journal, 2009, vol. 13, no. 3/4, pp. 229-264.

Taffler, R.J., and Tseung, M. 1984. The audit going concern qualification in practice - exploding some myths. The Accountants' Magazine July: 263-269.

Theodossiou, P.; Kahya, E.; Saidi, R.; and Phillipatos, G. 1996. Financial Distress and Corporate Acquisitions:Further Empirical Evidence. Journal of Business Finance and Accounting 23: 699-719.

Tirapat, S., and Nittayagasetwat, A. 1999. An Investigation of Thai Listed Firms' Financial Distress Using Macro and Micro Variables. Multinational Finance Journal, vol. 3, no. 2, pp. 103-125).

Treacy, W.F., and Carey, M. 2000. Credit Risk Rating Systems at Large U.S. Banks. Journal of Banking and Finance 24: 167-201.

Unal, H. 1988. An Early Warning Model for Predicting Firm Failure and Bankruptcy. Studies in Banking and Finance 7:141-170. 